\title{
Querer ser otro
}

doi: http://dx.doi.org/10.32870/espiral.v22i64.2927.g2654 Rafael Miranda Redondo •

La autora de este texto lleva a cabo un excelente ejercicio para abordar una temática de la vida cotidiana: el arreglo corporal por parte de jóvenes mujeres indígenas y mestizas emigradas a San Cristóbal de las Casas, Chiapas, dándole un interesante realce a nivel antropológico e histórico. Se aprecia mucho en la lectura la inclusión de pasajes biográficos vinculados con la elección de la temática. La figura paterna y, en particular, la relación con la madre de la autora son asuntos referidos al inicio, y en lo sucesivo se diluyen en el texto, que a partir de ahí habla explícitamente sólo de las otras y los otros. No obstante, esos pasajes biográficos y su ubicación en las primeras líneas del documento hacen pensar en que lo que ahí se describe tiene un lugar iniciático para el resto de lo que se dice. Es en todo caso desde ahí que la autora nos habla.

La consideración, iniciática, repito, de esos pasajes -aunque relativamente escuetos-me hizo pensar mucho en el etnopsicoanalisis de George Deveraux, y, sobre todo, en el análisis de la transferencia y la contratransferencia que conlleva todo proceso de conocimiento, lo que otros autores del institucionalismo francés -René Loureau, por ejemplo- han denominado el análisis de la implicación o del lapsus del intelectual;

Tania Cruz Salazar (2014). Las pieles que vestimos. Corporeidad y prácticas de belleza en jóvenes chiapanecas. Guadalajara: UNICACH, CESMECA, ECOSUR.
Coordinador general de la Cátedra Interinstitucional Cornelius Castoriadis y miembro del colectivo de bibliógrafos de Cornelius Castoriadis/ Agora International. alloiosis@hotmail.co.uk 
esas corrientes que, con la propuesta de Cornelius Castoriadis, han desmentido que el psicoanálisis haya muerto, como lo hubiera vaticinado felizmente el pensamiento posmoderno al referirse a los "grandes relatos". Muy por el contrario, el psicoanálisis como teoría y como practica poietica -del griego, "creación de sentido nuevo"- sigue siendo un potente recurso para abordar la dimensión imaginaria de la sociedad. En efecto, con la excepción hecha, por supuesto, respecto a los prejuicios que Sigmund Freud tenía cuando abordaba la sexualidad femenina, el psicoanálisis sigue representando - por ejemplo, para Judith Butler, citada en el texto aquí reseñado- un recurso laico para relacionarse con el otro que nos habita.

Es en esta perspectiva que, a lo largo de la lectura, hice un ejercicio de lo que llamo "la clínica de la alteridad", y que la autora, de algún modo, practica o por lo menos sugiere. La interrogación de entrada es ¿en dónde, a través del arreglo corporal, se busca ser otro, y hasta dónde se trata solamente de un simulacro de ocultamiento de la alteridad propia? A partir de la lectura del texto, pareciera que estamos ante el arreglo corpóreo "enculturado" como el simulacro para ser otro.

Ese simulacro sugiere entonces, si no la apertura ante, sí la curiosidad no sólo por la otredad sino, sobre todo, por la alteridad. La alteridad que nos habita como inconsciente, como institución y como imaginario radical creador. Institución que, en tanto que es mundo de significaciones imaginarias sociales, habla por nosotros como "formación discursiva", si se quiere, haciéndonos individuos sujetados, pero también como la instancia respecto a la cual se puede tejer una relación distinta resignificándola, alterándola y, por lo tanto, alternándonos.

Entiendo por alteridad, del griego alloiosis, y por reconocimiento de la alteración de lo dado, una dimensión cuyo reconocimiento tiene una venerable ancianidad, en todo caso 
infinitamente anterior a la mistificación del deconstruccionismo y los otros "des-". Pero entonces, querer explícitamente alterarnos -aquí el salto al vacío- en una relación distinta con aquello que está en nuestro origen, supone necesariamente reconocer como valor, orgánicamente ligado a la mejor modernidad, el de la autonomía propia y ajena.

Cierro el ejercicio. En este sugerente libro la autora nos brinda los elementos fundamentales para situar histórica y socialmente la reflexión esquemáticamente presentada en líneas anteriores, y, diría yo, la posibilidad de imaginar esa relación distinta con la institución propia de quien practica el arreglo corporal, la cultura de origen, la institución propia de las mujeres que migran a San Cristóbal, o el padre como fuente exclusiva de sentido.

Ahora bien, una vez que precipitamos la reflexión del ejercicio anterior a lo histórico-social, la cosa se complica. La significación imaginaria social que subyace a la explicitación y la práctica del querer ser otro, por ejemplo, en el arreglo, es un valor positivo vinculado con los orígenes de la ruptura que supone el nacimiento de la filosofía y la democracia, y por ende vinculado a su vez con la modernidad como revés ante la verdad revelada. Una ruptura que, al unir la institución propia con el nomos y no más con la phisis, asumirá el carácter trágico de la existencia, carácter a partir del cual podemos interrogarnos: ¿qué pasa cuando perpetuamente el instituyente que subyace a dicha relación, distinta con la institución propia, es recuperado -por la institución y por la institución que subyace al capitalismo y que tenemos interiorizada-, convirtiendo nuestros deseos en deseos de consumo? ¿Qué tiene que ver el deseo de ser otro, como instituyente que arremete contra la institución de lo dado, con la repetición en la institución de "soy totalmente Palacio"? ${ }^{1}$

I. El Palacio de Hierro es una cadena de tiendas, sobre todo de ropa, que ha marcado el curso de la moda de la clase media, en particular la femenina, en los últimos 50 años en México, y cuyo eslogan es “soy totalmente Palacio”. 
Es cierto que la modernidad corriente, reciclada hasta la saciedad por el capitalismo, nos quiso hacer creer que todo lo nuevo es bueno y todo lo viejo, malo. Sabemos que esto es falso, pero ¿quién decide cuál es la "buena figura" de quién la ostenta? ¿El Palacio de Hierro? ¿Los antropólogos y consultores posmodernos de paso por San Cristóbal en búsqueda de malinches, igualmente posmodernas?

Aquí de nuevo emerge relevante el análisis de la implicación respecto al propio "objeto de estudio", ausente en la mayoría de las corrientes de la antropología, y que la autora sugiere al inicio de su texto al momento de posicionar su biografía como lugar iniciático, análisis de la implicación que deja al descubierto lo que vaticina Marc Augé -también citado en el texto-, cuando habla de la "crisis de alteridad". Verse a sí mismo como objeto de estudio, accediendo así a la reflexividad, pareciera un propósito entre líneas que recorre el texto de inicio a fin.

La otra versión, o las otras versiones, corresponden a la interiorización, nunca hecha explícitamente en el positivismo científico más recalcitrante -en donde incluyo por supuesto al marxismo-, de la categoría de la determinidad, por la cual se aspira a mantenerse al margen en los procesos de conocimiento, y en especial respecto a su dimensión imaginaria, o por otro lado, a contracorriente de lo anterior, la interiorización -en las formaciones discursivas y su ineluctabilidad, por ejemplo, en un intento por posicionarse respecto al sujeto substancia- de figuras igualmente trascendentes, pero en este caso acompañadas de una cultura de la sospecha, por ejemplo, en los feminismos inspirados en la obra -ampliamente citada-de Michel Foucault.

El relativismo cultural, y otros que se derivan de ese rechazo del sujeto sustancia -este caso nuevamente arropado por la filantropía en la academia señalada por Deveraux-, es el que hace posible -aquí de nuevo el divorcio del filósofo respecto a la comunidad política-que los luchadores

\section{6}


por la "descolonización" no tengan que interrogarse sobre por qué eligen parejas que son ciudadanos de los antiguos imperios; que las feministas no tengan que interrogarse por qué tienen como amigos del alma a machos arrogantes; que los marxistas recalcitrantes no tengan que interrogarse por qué buscan sus parejas entre las hijas de los grandes industriales; que los contestatarios de los gobiernos vinculados con los cárteles de la droga no tengan que cuestionarse nada cuando, periódicamente, entregan su cuota a dichos cárteles para satisfacer sus consumos; que, finalmente, los expertos en migración no tengan que interrogarse sobre el hecho de que ellos nunca han migrado; y así sucesivamente.

Todo esto gracias a la teología racional -o a su equivalente en el universo relativista, que equipara el Réquiem de Mozart a un par de botas-, que profesa que el filósofo puede vivir al margen de la comunidad política porque de ser pastor pasó a ser tejedor para, finalmente, consagrarse como epistemon (Platón), es decir, como quien posee la ciencia que lo acredita para pensar al margen del hacer.

El tema de cómo los pueblos indios u originarios se enfrentan a -o significan o no- esa modernidad que nos da vergüenza, y del "libérate comprando esta lavadora", es sin duda un tema apasionante. El desafío que supone es asumido por la autora y conlleva el riesgo de relativizar, al punto de decir que todo vale, y que si los pueblos indios abandonan el pozol por la Coca-Cola, hay que suscribirlo porque "están manejando su cultura". La autora del texto Las pieles que vestimos nos presenta una visión mucho más compleja. El sujeto del arreglo corporal se crea $-\mathrm{y}$, diría yo, se autoinstituye, se autoaltera- a través de las tecnologías de género, pero ese mismo sujeto también, y por periodos prolongados, usando este recurso, se repite en el ocultamiento de la alteridad, gracias a las significaciones imaginarias sociales que el consumo, pero también que la 
institución que está en sus orígenes y le confiere la "identidad", le ofrecen.

A lo largo de la lectura de este sugerente texto fue inevitable que me acompañara, en el trasfondo, la anécdota de Sócrates, quien preguntó a su madre: "Madre, ¿por qué soy tan feo?", a lo cual su madre respondió: "Sócrates, no eres feo, eres diferente". 